\title{
Visions of Diversity: Cultural Pluralism and the Nation in the Folk Music Revival Movement of the United States and Canada, I958-65
}

\author{
GILLIAN A. M. MITCHELL
}

\section{INTRODUCTION}

This article focusses on the concept of cultural pluralism in the North American folk music revival of the ig6os. Building on the excellent work of earlier folk revival scholars, the article looks in greater depth at the "vision of diversity" promoted by the folk revival in North America - at the ways in which this vision was constructed, at the reasons for its maintenance and at its ultimate decline and on the consequences of this for anglophone Canadian and American musicians and enthusiasts alike. ${ }^{1}$

Revival scholars such as Neil Rosenberg, Ronald Cohen and Robert Cantwell have highlighted, and shown considerable understanding of, the cultural and musical pluralism which the folk revival promoted and celebrated, but none have sustained a uniform focus on its origins, its consequences or its development beyond the mid-I 960 s. $^{2}$ This article aims

Gillian A. M. Mitchell is a lecturer in American History at the University of Wales, Bangor, Gwynedd, North Wales.

${ }^{1}$ For the purposes of this article, henceforth "Canadian" is intended to signify "anglophone Canadian." Although English-speaking revivalists in Canada valued and expressed fascination for the music of Quebec, the aims, outlook and desires of Quebecois folk musicians and revival participants were, in many ways, different from those of their anglophone counterparts, and it would not be possible to do justice to the complexities of their movement here.

${ }^{2}$ Neil Rosenberg, ed., Transforming Tradition: Folk Music Revivals Examined (Urbana, IL: University of Illinois Press, I 993); Ronald D. Cohen, Rainbow Quest: The Folk. Music Revival and American Society, 1940-1970 (Amherst: Massachusetts University Press, 2002); and Robert 
to offer an introduction to this subject, framed within a broader historical summary of the movement up to $1965 .^{3}$ Since the 1930 Americans had begun to celebrate the diversity of their country and to appreciate the great variety of music and cultures in its many regions; the folk revival of the late 1950 s and early i960s was the point at which this vision of diversity reached its peak, promoted and revelled in by young people who embraced the idealism of civil rights and Peace Corps politics. Such findings may appear self-evident; however, less easy to predict was the way in which this American-centric ethic was received and adapted by the folk revival of Canada, northern neighbour of the United States.

Canada's popular music history, although receiving much attention from journalists and popular authors, has, generally, been overlooked by scholars. ${ }^{4}$ The assumption is often made that any study of the subject will arrive at the nihilistic conclusion that Canadian music is solely imitative of and derived from American and British trends. While there is no doubt that trends originating outside the country have given shape to Canadian music throughout the history of the nation, Canadians are more than passive receptors of extraneous musical styles. Indeed, such a one-dimensional understanding of the cultural dynamics of popular music fails to account for such phenomena as, for example, "the British invasion," a British response to music of American origin which, in turn, became tremendously influential upon Americans in the mid-ig6os. All forms of popular music, folk revival music included, constitute adaptation, translation and a claim to shared artistic ownership, regardless of the geographical origins of the "root" music style. Such a conception of the universality of music would not have met with the approval of revivalists who upheld the integrity of "authentic" musical traditions. However, it is certainly the case that, although the folk revival did, to some degree, represent an American commercial trend

Cantwell, When We Were Good: Class and Culture in the Folk Revival (Cambridge, MA: Harvard University Press, 1996).

3 The article is part of a broader work in progress on the concept of nation and national identity in the folk revival of the United States and Canada from the early twentieth century to the 1980 s.

4 Among the small number of academic studies of Canadian popular music are Robert A. Wright, "Dream, Comfort, Memory, Despair: Canadian Popular Musicians and the Dilemma of Nationalism, 1968-1972," in Beverley Diamond and Robert Witmer, eds., Canadian Music: Issues of Hegemony and Identity (Toronto: Canadian Scholars' Press, I994), 283-301; and Barry K. Grant, "Across the Great Divide: Imitation and Inflection in Canadian Rock Music," Journal of Canadian Studies, 2 I (1986), I I6-27. The Quarry Press, based in Kingston, Ontario, has produced a series of popular biographies of Canadian popular musicians, including Neil Young, Ronnie Hawkins (an adoptive Canadian), Ian Tyson and Gordon Lightfoot. 
adopted by Canadians in the I960s, the tremendous breadth, diversity and almost chaotic pluralism of the revival's musical and cultural outlook meant that Canadians, in the early ig6os at least, were able to make the revival fully their own. The blending of the national, the international and the local which the revival promoted allowed Canadians to feel, in many respects, that they were participating in, and taking ownership of, what was truly a "North American" movement in many senses - a multi-ethnic, multiregional, localized and transnational movement.

\section{BACKGROUND: UNDERSTANDING THE NATURE OF THE FOLK REVIVAL}

At the dawn of the twenty-first century we remain surrounded by the legacy of the folk revival. Musicians who provided the active sociopolitical conscience of what Neil Rosenberg called the "great boom" of the movement in the r950s and 1960s - including Tom Paxton, Pete Seeger and Joan Baez - have continued, over the years, to emphasize the linkage between folk-style protest music and political activism. ${ }^{5}$ Bob Dylan, perhaps the most famous protégé of the movement, despite his fabled 1965 rejection of its principles and perceived strictures, continues as a significant artistic presence, his desire to create undimmed as he enters his sixties. ${ }^{6}$ Most significantly, the recent publication of the first instalment of his autobiography, and his last album Love and Theft, demonstrate that Dylan is more prepared now than ever before to acknowledge, and even celebrate, his folk music roots before a contemporary audience. The folk revival was also reintroduced to the public eye via the gentle, well-observed mockery of the 2004 film A Mighty Wind. Produced by the creators of This is Spinal Tap, the film poked fun at the many idiosyncrasies of the revival, including its political "hang-ups," its abhorrence of commercialism and the eccentric personalities which became its foundation. ${ }^{7}$ Although neither as successful nor as well received as Spinal Tap, the film afforded the long-overdue opportunity to laugh, if perhaps somewhat wistfully, at a movement whose optimism, earnestness and naivety appeared so anachronistic amid the controversy and chaos of America in the post-9/i i era.

5 Rosenberg, 2-3. Regarding the continuing activism of older protest singers, when Tom Paxton performed at Hugh's Room, a popular venue in Toronto, in early 2004, his set comprised both older, "classic," protest songs and a new song about the bravery of firemen on i september 200I.

${ }^{6}$ Bob Dylan, Love and Theft (2003); Bob Dylan, Chronicles, Volume One (New York: Simon and Schuster, 2004).

7 A Mighty Wind, dir. Christopher Guest (2003). 
Despite its professed dislike of commercialism, the folk revival did, inexorably, become imbued with the values of mainstream popular culture. "Stars" and "names" were created, and many who began their careers performing protest songs in small-town coffee houses - Paul Simon, Joni Mitchell, James Taylor and Janis Ian, to name but a small selectionproceeded to become world-renowned "singer-songwriters." However, as the principal scholarly histories of the movement demonstrate, the folk revival was considerably more multi-faceted than the careers of individual ex-revivalists would suggest. ${ }^{8}$ Surrounding these well-known individuals were scores of musicians, enthusiasts, collectors and students who cared little for guitar-toting rebels like Dylan or Paxton, but who joined the ranks of the revivalists in order to satisfy their deep curiosity about the most specific of music styles - be it Chicago blues, calypso music, Appalachian string-band music or New Orleans jug-band music. Their heroes were the unsung traditional musicians who continued to live in rural obscurity while playing their music in the most "pure" and "authentic" manner possible. It is vital to recognize that the legacy of the folk revival stretched beyond the careers of well-known, individual singers; it could be argued, in fact, that the most important consequence of the movement was its laying of the foundations for contemporary "world music," now a fixture of major significance in the music industry. The love of ig6os revivalists for musical specificity and unusual musical styles helped to create our contemporary appreciation of the infinite variety of music throughout the world. The folk revival, in short, helped to embed the concept of musical pluralism into the consciousness of North America and the Western world in general.

The pluralist character of the folk revival was, partially at least, inherited from the "first wave" of the revival in the i940s and early i950s (a movement largely comprised of northern, urban leftist intellectual types) and from the cultural movements which had originally informed this initial revival most notably the activities of early folklore collectors and the inclusive, folkcultural spirit of the Federal Arts Projects of the Great Depression era. ${ }^{9}$

8 This is demonstrated particularly by the many essays in Rosenberg. The book divides the music of the revival into three sections - "traditional" music, "new aesthetic" music (i.e. the music of performers such as Dylan or Baez who used folk styles in their own compositions) and "named systems" revival music (i.e. the revival of a very specific style of folk music, such as Appalachian fiddle or bluegrass). Ellen Stekert's i 966 essay "Cents and Nonsense in the Urban Folksong Movement: I 930-66," reprinted in Rosenberg, 84-107, demonstrates a contemporary understanding of this diversity.

9 The New Deal Arts Projects endeavoured to present a vision of America which embraced all social and ethnic groups. For more information see Jerrold Hirsch, Portrait of America: A Cultural History of the Federal Writers' Project (Chapel Hill and London: University of North 
Folklorists such as the Americans John and Alan Lomax and the Canadian Marius Barbeau had infused their profession with new dynamism as they sought to demonstrate the variety and diversity of North American folklore and folk music, aided by new developments in recording technology. ${ }^{10}$ As the Lomaxes and Barbeau worked to reinvigorate the discipline of folklore in North America, their inclusive approach to folk culture was furthered by the work of the New Deal Works Progress Administration's cultural projects during the I930s in America. Historians of New Deal culture have suggested that the trauma of economic crisis caused Americans to search for spiritual nourishment and antidotes to the overblown materialism which had brought so much catastrophe and misery to their country; their thirst for folklore was reflected and promoted by the WPA projects in the form of state guides, ethnomusicology projects and folk art-inspired murals. ${ }^{11}$ While Canada had no direct "equivalent" to American New Deal culture, both countries experienced a resurgence of left-wing political activity during the I930s, a phenomenon which was to provide another crucial foundation for the folk music revival. The anti-fascist Popular Front, launched by the Communist Party in 1935, and giving particular credence to the various cultures and customs of the "ordinary people," gained support among a broad spectrum of left-leaning artists and thinkers in both Canada and the northern cities of America. ${ }^{12}$ The first incarnation of the folk music revival in the I940s, with its politically inspired square dances and "hootenannies," was a direct consequence of this new passion for the culture of the people.

The temporary decline of this "first wave" of the folk revival during the anticommunist I950s, and its resurgence following the success of the

Carolina Press, 2003); and Barbara Melosh, Engendering Culture: Manhood and Womanhood in New Deal Public Art and Theatre (Washington, DC and London: Smithsonian Institution Press, I991).

${ }^{10}$ See Nolan Porterfield, Last Cavalier: The Life and Times of John A. Lomax (Urbana; IL: University of Illinois Press, I996); Benjamin Filene, Romancing the Folk (Chapel Hill and London: University of North Carolina Press, 2000), Jerrold Hirsch, "Modernity, Nostalgia, and Southern Folklore Studies: The Case of John Lomax," Journal of American Folklore, ios (1992), I 83-207; and Lawrence Nowry, Man of Mana: Marius Barbeau (Toronto: NC Press, 1995). David Whisnant's study, All That is Native and Fine: The Politics of Culture in an American Region (Chapel Hill and London: University of North Carolina Press, 1983), deals with the history and development of traditional perceptions of the Appalachians. See also Jane Becker, Selling Tradition: Appalacbia and the Construction of an American Folk, 1930-1940 (Chapel Hill and London: University of North Carolina Press, 1998).

11 For more information see Jerrold Hirsch, Portrait of America, and Barbara Melosh, Engendering Culture.

12 See Michael Denning, The Cultural Front: The Labouring of American Culture in the Twentieth Century (London and New York: Verso, 1996), 5, and Filene, 70. 
Kingston Trio's polished folk-styled single "Tom Dooley," has been well documented elsewhere. ${ }^{13}$ By the early i 960 s the "old left" politics of the first wave of the revival were replaced by the optimistic participatory democracy of the New Left and the liberal, integrationist politics epitomized, or at least symbolized, by John F. Kennedy and Martin Luther King, but the belief that folk music represented and promoted a vision of a diverse North America gained in strength in the early i96os, and was shared by Americans and Canadians alike.

\section{CREATING A DIVERSE MOVEMENT: COFFEE HOUSES, FOLK FESTIVALS AND MAGAZINES}

The very nature of the folk revival in the "boom" years was predisposed to promote cultural diversity. The movement embraced chaos and contradiction; not all of its participants welcomed its catholicity, but, nonetheless, a diverse array of musical styles was brought together under the umbrella of the revival. The very "apparatus" of the folk revival - principally the coffee houses and festivals at which revivalists gathered, and the magazines which they read - worked to ensure that diversity and universality remained fundamental features of the movement.

Coffee houses had, by the early i 960s, become vital gathering-places for folk musicians across North America. The epicentre of the coffee-house scene was in New York City, and particularly in the Greenwich Village area, where, responding to the tastes of many of their clients, coffee-house owners often booked jazz artists - Chet Baker, Charles Mingus and John Coltrane made regular appearances around the Village. ${ }^{14}$ By the early i96os, as folk music became increasingly popular among young intellectuals of the neighbourhood, coffee-house owners responded by promoting their premises as folk music venues where well-known musicians could perform, and where budding talents could experiment. In Greenwich Village, by the early I 960 , folk music could be heard at, among other places, the Café Wha?, the Village Vanguard, Gerde's Folk City and the Gaslight.

Coffee-house "culture" spread throughout North America, as young folk music enthusiasts sought suitable venues in their local area, and as

13 Robert Cantwell, "When We Were Good: Class and Culture in the Folk Revival," in Rosenberg, Transforming Tradition, 35-60. Cantwell also discusses the significance of the Kingston Trio in the Prologue to his monograph, When We Were Good: The Folk Revival (Cambridge, MA and London: Harvard University Press, I996), I-Io.

14 For an interesting contemporary account of the Greenwich Village "scene" see Thomas J. Fleming, "Greenwich Village: The Search for Identity," Cosmopolitan, Dec. 1963. 
entrepreneurs recognized the commercial potential of folk music. ${ }^{15}$ These coffee houses were local manifestations of an international movement and, as such, they helped to promote and encourage diversity through the presentation of a wide range of musical acts, and through the promotion and showcasing of all levels of talent. In major folk music neighbourhoods such as Greenwich Village and Yorkville, Toronto, amateur performers would be provided with the opportunity to showcase their material during "open stage" nights. In Toronto, for example "hoot nights" were held at the Bohemian Embassy coffee house throughout the early and mid-ig6os. These evenings were organized by the Toronto Folk Guild, a small, loose affiliation of folk music enthusiasts who first gathered in the late 1950s, and who would come to play an important role in the development of folk music in the city, and in Ontario at large. According to Toronto musician Ken Whiteley, Estelle Klein, who was the head of the Folk Guild, wished to promote as diverse a vision of folk music as possible, and everything from traditional singing, blues and poetry to jug-band and skiffle music was present at these "hoots."16

As significant as the diversity of music presented was the fact that these revival venues were welcoming and encouraging to amateurs as well as to famous professional performers. Indeed, amateurs had a whole range of potential venues from which to choose; in Greenwich Village, many of the "unknown" folk music performers would congregate in clubs and coffee houses known as "baskethouses" where they might perform short sets and subsequently obtain payment by passing a hat around the audience, while scores of amateur enthusiasts of all levels of ability would join in the weekly communal music sessions in Washington Square simply for enjoyment. ${ }^{17}$

Other establishments played key roles in encouraging the diversity of the folk revival in particular cities. For example, Israel Young's Folklore Center, which opened in Greenwich Village in 1957, was a vital magnet for folk music enthusiasts in New York; young people gathered there to listen to rare

${ }^{15}$ An interesting 1966 publication by the Denver Folklore Center provides a list of coffee houses in each major American city. See Harry M. Tuft, The Denver Folklore Center Catalogue and Almanac of Folk. Music Supplies and Information for the Fiscal Year 1966 (Denver: Denver Folklore Center, 1966), 195-98 (From the collection of the American Folklife Center, Library of Congress, Washington, DC).

${ }^{16}$ Ken Whiteley, interview with the author, Toronto, I 3 Jan. 2003.

17 The first Washington Square group sessions were held in summer 1946, but grew significantly in strength in the I950s. See George Margolin's account of the early sessions, "Sidewalk Hootenanny", People's Songs, 2, I and 2 (Feb. and March i 947). 
recordings, buy books and discuss folk music with the gregarious owner. ${ }^{18}$ The Old Town School of Folk Music, also established in 1957 by Frank Hamilton and Win Stracke, played a comparable role within the Chicago "scene." The school, which provided instrumental instruction, lecture series and a forum for discussion for young folk enthusiasts, aimed to encourage local talent, and to foster a view of folk music which was all-embracing, with emphasis placed on "social" learning, rather than rigorous, "classical" training. ${ }^{19}$ Coffee houses, and other, similar venues, were crucial in the promotion of diversity within the folk revival of the late i950s and early i $960 s$. They provided a local "framework" for a movement which had grown to national proportions, they promoted all levels of talent and they encouraged a plethora of musical styles.

Folk music festivals also helped to promote the diverse character of the folk revival during the late i950s and early i 960 . Folk festivals were not innovations of this era. However, the folk festival which became particularly central to the "great boom" of the I96os was the Newport Folk Festival, held in Newport, Rhode Island. Each year Newport featured a tremendous variety of acts; for example, in 1964, according to Sing Out!, the festival showcased "a melange of 'big names' coupled with lesser-known traditional talent and up-and-coming city artists." ${ }^{20}$ Southern and Western American music styles were presented, as was the music of other ethnic and cultural groups within America. Folk revival participants often sought to be informed as well as to be entertained, and thus academic perspectives on folk music were provided at the 1964 festival by distinguished folklorists such as D. K. Wilgus and Alan Lomax. ${ }^{21}$

The Mariposa Folk Festival emerged in I96 I as a Canadian parallel to the Newport Festival. The initial festival was organized by Ruth Jones, Crawford Jones and Pete McGarvey, and was held in Orillia, a small town north of Toronto. ${ }^{22}$ The original festival was a very small-scale affair, but gradually it grew in strength and began to feature a diversity of performers - a mixture of the traditional and the neo-traditional, the popular folk "stars," the

18 John Cohen (II), in Ronald Cohen (ed.), “Wasn't That a Time!": First Hand Accounts of the Folk Revival (Metuchen, NJ and London: Scarecrow Press, I995), i 80.

19 Frank Hamilton, in ibid., I $56-57$. See also a letter excerpt from Frank Hamilton regarding the progress of the school, printed in the folk music magazine Caravan, March i 958.

20 Paul Nelson, "Newport: The Folk Spectacle Comes of Age," Sing Out! 14, 5 (Nov. 1 964), 8. The American Folklife Center of the Library of Congress, Washington, DC, has a collection of Newport Folk Festival Programmes from I959 to 1969. ${ }^{21}$ Ibid., 6-I I.

${ }^{22}$ Canadian writer Stephen Leacock (I 869-1 944), who had been born in Orillia, had written a number of "sketches" in which he gave his hometown the fictitious name of "Mariposa" - hence the name of the Festival. 
commercial and the unusual, from Canada, America and beyond. The festival programmes comprised short biographies of the performers as well as educational articles and essays on specific folk music styles; folklorist Edith Fowke contributed a piece on Ontario folk music and Leigh Cline wrote an article on old-time music. ${ }^{23}$

Newport and Mariposa were both highly diverse festivals, and many former participants saw no need to interpret their agendas as having been anything other than a desire to represent as many styles of folk music as possible. Nevertheless, Newport was the larger gathering, and it pre-dated the Canadian festival by a year; it may, therefore, be worthwhile to consider the extent to which the Mariposa organizers were concerned with creating a festival which was not "in the shadow" of Newport, and whether or not issues of "Canadian-ness" played any part at all in their agenda. Evidently some organizers and commentators did think that Mariposa should be a "Canadian" festival; considerable attention was given to this issue in a 1963 edition of Hoot magazine, a Canadian revival periodical. Ed Cowan, publicity director for Mariposa in 1963 , suggested that the creation of a nationally focussed perspective had been "the hottest single issue" for the festival, and that Canadian performers were being urged by many to collect and present more Canadian material. ${ }^{24}$ Jack Wall, director of the festival that year, stated, in the same magazine, that it was his aim to make Mariposa "a truly Canadian event." Neither contributor explained in detail what constituted a "Canadian" sound - that is, whether Canadian music was simply a form of folk music which originated firmly in Canada, or whether its "Canadian" quality was something less evident which had to be discerned by intuition. ${ }^{25}$ However, the brief pieces in this edition of Hoot certainly seem to suggest that discourse on the folk revival and on its relationship with Canadian identity was both prolific and significant.

However, it is arguable that those who wished to "Canadianize" the Mariposa festival in this way were not the representative majority, but merely a small faction within the organizing committee and audience. The folklorist Edith Fowke helped to promote a "Canadian" focus at Mariposa. Fowke, who contributed a great deal to workshops and programmes at the

${ }^{23}$ Programme for the Mariposa Folk Festival, held at Innis Lake, Ontario, 5-7 Aug. I 966 (Toronto Public Library, Central Branch, Vertical Files).

24 Hoot magazine, issue I, Aug. 1963.

25 This would prove to be a lingering problem for cultural nationalists in Canada. Assumptions were frequently made that, if Canadians were afforded sufficient opportunity, they would naturally make "Canadian" music. However, defining the "Canadian" element of the music remained very difficult. 
Mariposa Festival, frequently emphasized the virtues of Canadian traditional songs (especially those originating in Ontario) because of her strong belief in the particular purity and integrity of music passed down through oral traditions. Ruth Jones, one of the founders of Mariposa, was also, apparently, concerned with emphasizing the "Canadian" qualities of the festival. ${ }^{26}$ Their viewpoints were, however, contrasted with that of Estelle Klein, another profoundly influential organizer of Mariposa, who directed the Festival from the late I96os until 1980. Ken Whiteley perceived Estelle Klein to be most broad-minded in her definition of folk music and in her view of what the Mariposa Festival should represent. ${ }^{27}$ Klein was greatly influenced by the eclectic nature of the Newport Folk Festival, and hoped to create, in Mariposa, a festival of a similar breadth and diversity. She was not overly concerned with the creation of a "Canadian" festival, although fellow organizers continued to believe that this was a priority. Feeling the necessity to provide for young folk music enthusiasts "a breadth of knowledge" of their subject of interest, she set about bringing in as great a diversity of musicians as possible. ${ }^{28}$ By the early I 970 os she had established, at Mariposa, workshops for Native culture and for francophone folklore, and she would attend small festivals organized by particular ethnic groups and invite some of their participants to appear at Mariposa. ${ }^{29}$ For Klein, therefore, the idea that the Mariposa Festival should be recognizably "Canadian" was not as significant as the drive to make the Festival, like its sister festival in Newport, as varied as possible. ${ }^{30}$

The magazines of the revival also served to encourage further this fascination with musical diversity. Sing Out!, which had begun in 1946 as the left-wing People's Songs Bulletin, had by the early ig6os become a widely read and widely available publication. ${ }^{31}$ Although it retained much of its political character, the magazine was, by the early I96os, a compendium of brief articles on multifarious styles of music, which presented a wide range of opinions and, indeed, definitions of folk music. While Irwin Silber, the editor, remained the political spokesman of the "old guard" of the movement, Israel Young and Pete Seeger showed more willingness to embrace

${ }^{26}$ Ken Whiteley, interview, and Estelle Klein, telephone conversation with the author, I April 2004. A small archive of material from the early Mariposa Festivals is held at the National Archives of Canada, Ottawa.

${ }^{27}$ Ken Whiteley, interview.

${ }^{28}$ Estelle Klein, telephone conversation.

${ }^{29}$ For example, Klein met a troupe of Portuguese "stick dancers" at a Portuguese Festival in Toronto, and invited them to appear at Mariposa in the early i 970 .

${ }^{30}$ Richard Flohil, interview with the author, Toronto, 6 May 2003.

31 The magazine was renamed in 1949 . 
the many more commercialized forms of folk music which had begun to flower in the early ig6os.

Of all the regular contributors to Sing Out!, Pete Seeger was most encouraging of a diverse perspective on the music of the United States. As a political campaigner and enthusiastic folk-song collector, he had spent his life travelling around the country and beyond, and in each edition of the magazine, in his "Johnny Appleseed Jr." column, he recounted tales of his musical and cultural discoveries. Benjamin Filene has argued that Pete Seeger had a particular appeal for many young revivalists because his background as a middle-class, former Harvard student was most similar to theirs; he revealed to them, through his experiences, that the workaday world of "the folk" might be accessible to them. ${ }^{32}$ Hence his columns for the magazine, collected in edited form in his autobiographical work The Incompleat Folksinger, helped to form, in the minds of his younger followers, impressions of a world of cultural richness and infinite diversity, a world in which they might have a share, whatever their cultural background - or perceived lack thereof. As he admitted,

I am several generations away from whatever folk traditions my great-grandparents had. Now, suddenly I come along and realize my paucity and try and recapture a few traditions. ... My own solution has been to try and learn from other people. I have learned from Negro people, from Jewish people, from Ukrainian people and many others. $^{33}$

Seeger was thus particularly significant in shaping the universalistic dynamic of the revival, particularly through his writings in Sing Out!

Sing Out! was, arguably, one of the most catholic of the folk revival periodicals, catering to the broad spectrum of folk music fans (with the possible exception of those who loved the most commercial of folk music performers) and attempting to reach and respond to as wide a range of readers as possible. However, other major folk music magazines of the "boom" period were more specialized and specific in their outlook and intentions. These arguably served to complement the broader perspective of Sing Out! and to respond to, and shape, the interests of those readers who had more particular opinions on what folk music should be. For example, Broadside magazine was begun in the early ig6os by Agnes "Sis" Cunningham, a former member of the left-wing Almanac Singers. ${ }^{34}$ This magazine was purely a compilation of music and lyrics for new and old

32 Benjamin Filene, Romancing the Folk, 204.

33 Pete Seeger, The Incompleat Folksinger, ed. Jo Metcalf Schwartz (New York: Simon and Schuster, I972), 544 .

34 The origins of Broadside are briefly discussed in Ronald Cohen, Rainbow Quest, I79-83. 
topical songs from all over the world. This emphasized and reflected the interests of those revivalists who believed that folk music should continue to be an instrument of social protest, and also encouraged young people to become more involved in the folk music movement by learning to perform these songs for themselves. The magazine was also an important vehicle for new songwriters - the songs of Bob Dylan and Phil Ochs, among others, were first published in Broadside.

Equally important to the promotion of diversity in the revival, however, were the small-scale, individualistic and often eccentric periodicals known as "fanzines." Among such publications were Gardyloo, which existed for a short time during the late 1950s, and Caravan, begun by Lee Shaw in $1957 .{ }^{35}$ However, perhaps the most unique, and significant, of such "fanzines" was the Little Sandy Review. Begun in 1959 by Paul Nelson and Jon Pankake, two devotees of folk music, the small, cheaply produced magazine consisted solely of reviews of folk records, concerts and festivals. The original edition of the magazine contained a revealing statement from the editors concerning their outlook and purpose:

Our creed is a very simple one. We are two people who love folk music very much and want to do all we can to help the good in it grow, and the bad in it perish. After reading this issue, it should be very apparent to anyone who we think is good and who we think is bad and why. ${ }^{36}$

Between 1959 and 1965 the Little Sandy Review devoted itself to the promotion of "good" folk music, and the merciless condemnation of "bad" folk music. Its notion of what was "good" basically included all traditional musicians and those who appeared, in their view, respectful of tradition. ${ }^{37}$ Those musicians whom they deemed "bad" were, conversely, mocked unmercifully; anything commercial in orientation was dismissed as "folkum" (their term for "phoney" folk music), while the efforts of popular performers such as Joan Baez, Judy Collins and Bob Dylan seldom met with approval. $^{38}$ The opinions of the Little Sandy editors as to what

35 Copies of Caravan from No. I (August 1957) to No. I4 (Dec. 1959-January 1960) are held in the American Folklife Center, Library of Congress, Washington, DC. The Folklife Center holds two or three editions of Gardyloo from the late i950s.

${ }^{36}$ Little Sandy Review, No. I (1959). See also Ronald Cohen's brief discussion of the magazine in Rainbow Quest, 164-68.

${ }^{37}$ Little Sandy Review, No. i I (c. early i 96 I - many issues were not dated). John Cohen wrote to thank Nelson and Pankake for their support in late 1960, and the letter was published in $L S R$, I, Iо. Cohen also began to contribute a column to the magazine in the early ig6os.

38 The term "folkum" was defined as "phony" folk music in the first edition of the magazine in 1959. In No. I4 (c. 1961) Judy Collins was described as "Elektra's contribution to the urban folk music revival's burgeoning Petticoat Brigade," while, in No. 27 (Dec. I963), 
constituted "good" folk music were, clearly, firm and highly specific, and grounded in a sense of traditionalist music. While it was in existence, the Little Sandy Review was the voice of the self-styled "experts" on folk music - those who were disdainful of commercial music and who wished to enter an "inner circle" of folk fans through knowledge of specific, particularly traditional, folk genres and performers. Its eccentricity and uniqueness of approach helped to enhance the diversity of opinions, and the awareness of different styles of music, within the folk revival.

Owing undoubtedly to its smaller population and folk scene, Canada had fewer domestically produced folk music magazines. Sing Out! was the preferred periodical of Canadians, and from around 1964 onwards it contained a regular column on Canadian singers and events, focussing particularly on Toronto. However, for a brief period of time, a magazine entitled Hoot! was produced by the Toronto Folk Guild; with smaller circulation and a limited budget, production of this magazine was irregular, and unlike those of Sing Out! its issues were not punctuated by vigorous debates over commercialism versus purism or authenticity versus imitation. However, Hoot! did share with its American counterparts an eclectic vision of the revival. One edition contained items on, among other things, old-time southern music, jug bands, black Canadian singer Jackie Washington, ragtime, Bulgarian music, Mike Seeger and Marie Hare, a Canadian singer. ${ }^{39}$ The magazine contained pieces on Canadian music, contributed by Helen Creighton, Edith Fowke and Estelle Klein, but not disproportionately so. As with the other periodicals of the revival and the music festivals, it reflected the desire of folk music enthusiasts to be knowledgeable about, and experience at first hand, as diverse a range of musical styles, particularly from the North American continent, as possible; apparently, the more obscure and "rare" these styles were seen to be, the more they were valued by the revivalists.

\section{CULTURAL DISLOCATION, POLITICS AND THE “EXCLUSIVE FACTOR": EXPLAINING THE PLURALISM OF THE FOLK REVIVAL}

The folk revival had developed in the I930s and I940s as a consequence of greater cultural awareness and toleration in North America, albeit exhibited by a comparatively small number of people. The revivalists of

Dylan's Freewheeling Bob Dylan was described as "a flat tire." Both Dylan and Baez were criticized in No. 29 (early I964).

39 Hoot magazine, 2, I, Jan. 1966. 
the postwar "boom" period, however, did not merely cling to this fascination with, and longing for, diversity and tolerance, but also developed it further via the media of their movement. Why had they done so? And, once again, to what extent did Canadian and American revivalists share or differ in their motivations?

The most commonly held view of the raison d'être of "great-boom" revivalists concerns their apparent longing for community and cultural identity in a sterile, mass culture-driven world. The sixties, or "baby-boom," generation which participated in the folk revival was a generation which grew up amidst comparative social and economic security. ${ }^{40}$ The Second World War had not only boosted the ailing economy and brought an end to the Depression that had blighted North America throughout the previous decade, but it had also left Canada and, particularly, America considerably wealthier than the rest of the world. In America, GIs and their families were given unique and unprecedented opportunities as the result of government legislation - including the chance to buy homes (in specially constructed suburbs) and the opportunity to attend university or begin more lucrative careers. ${ }^{41}$ Countless families, most significantly those of eastern and southern European Catholic and Jewish backgrounds, benefited from the legislation and commenced a middle-class existence. ${ }^{42}$ Considerable abundance and prevalent consumerism were characteristics of life, at least for many white Americans, in the i950s. ${ }^{43}$

The conditions of Canada after I 945 were not necessarily as positive as those of America. Historian Valerie Korinek has challenged the enduring myth that "endless affluence and good times" prevailed in the Canadian

40 See, for example, the following overviews of the period: James Gilbert, Another Chance: Postwar America, 1945-1968 (Philadelphia: Temple University Press, 1981); and William H. Chafe, The Unfinished Journey: America Since World War II (New York; Oxford: Oxford University Press, 1995). Discussion of the postwar economy in Canada is included in Donald Creighton, The Forked Road: Canada 1939-1957 (Toronto: McClelland and Stewart, 1976); and Robert Bothwell, Ian Drummond and John English, Canada Since 1945: Power, Politics and Provincialism (Toronto, Buffalo and London: Toronto University Press, I989).

${ }^{41}$ Both Gilbert and Chafe devote considerable attention to the discussion of the GI Bill of Rights and its impact. See also Michael J. Bennett, When Dreams Come True: The GI Bill of Rights and the Making of Modern America (Washington and London: Brassey's Inc., I 996).

42 According to James Gilbert, the population of the New Jersey "Levittown" (mass produced housing development) in the early i 95 os was $47 \%$ Protestant, $37 \%$ Catholic and I $4 \%$ Jewish.

43 The consumer revolution of the postwar era has been of considerable interest to historians. The most recent study is Lizabeth Cohen's A Consumer's Republic: The Politics of Consumption in Postwar America (New York: Knopf, 2003). See also Lawrence B. Glickman, ed., Consumer Society in American History: A Reader (Ithaca and London: Cornell University Press, 1999), a comprehensive volume of essays, several of which discuss the immediate postwar era. 
suburbs after the war; she cites statistics of the period which illustrate that the overall standard of living in Canada was, in fact, lower than that of the United States. ${ }^{44}$ Korinek also suggests that many Canadian suburbs were not middle-class havens, but run-down working-class areas, a suggestion with which Veronica Strong-Boag, in her study of the hardships of European women in Canadian suburbs, concurs. ${ }^{45}$ However, despite differences between the two nations, there is no doubt that spending and consumerism increased in Canada after i 945. As Korinek herself suggests, "a modest level of affluence" was to be found in many of the Canadian suburbs, and advertisements, catalogues and technological revolutions reminded consumers that there was always the prospect of more. ${ }^{\mathbf{4 6}}$

It was into the world of drive-ins, suburban ideals and mass spending that the folk-boom generation was born; indeed, the prosperity, it could be argued, helped to shape them as a distinct group. James Gilbert has demonstrated that postwar white American teenagers stayed at school longer and were more independently affluent than previous generations. ${ }^{47}$ Young people in Canada, too, were to a considerable degree sharing in this greater economic and cultural independence. ${ }^{48}$ Because many white North American teenagers had never experienced serious economic hardship, they were often perceived to be self-confident, having been afforded the luxury of celebrating their youth rather than seeing it as an obstacle to socioeconomic advancement.

However, middle-class white youth was one of the groups most loudly protesting the perceived cultural disorientation and barrenness of postwar mass society, and in many ways the revival of folk music was part of the remedy for this sense of cultural sterility. ${ }^{49}$ Scholars such as Robert Cantwell look at the revival as an attempt by young middle-class white people to

${ }^{44}$ Valerie J. Korinek, Roughing It in the Suburbs: Reading Chatelaine Magazine in the Fifties and Sixties (Toronto, Buffalo and London: University of Toronto Press, 2000), 6. The statistics come from a 1965 study by John Porter entitled The Vertical Mosaic.

45 Veronica Strong-Boag, "Home Dreams: Women and the Suburban Experiment in Canada," Canadian Historical Review, 72 (1991), 47 I-504. $\quad{ }^{46}$ Korinek, 6-7.

${ }^{47}$ James Gilbert, Cycle of Outrage: America's Reaction to the Juvenile Delinquent of the 195os (New York: Oxford University Press, 1986), i 5-23.

${ }^{48}$ See Doug Owram, Born At the Right Time: A History of the Baby Boom Generation in Canada (Toronto, Buffalo and London: University of Toronto Press, I996).

49 Not all historians concur that the postwar era was a period of cultural sterility. See, for example, Joanne Meyerowitz, "Beyond the Feminine Mystique: A Reassessment of Postwar Mass Culture, I946-1958," Journal of American History, 79 (1993), I455-82, and Dominick Cavallo, "Middle-Class Child Rearing," in idem, A Fiction of the Past: The Sixties in American History (New York: St. Martin's Press, i 999), 43-62. 
regain some kind of ethnic and social identity for themselves whilst rejecting all in music that was, to them, overly-sanitized, mass produced and contrived. ${ }^{50}$ Many revival participants were second- and third-generation Europeans; their forebears had fought hard against prejudice and poverty to assimilate into North American society, and in the climate of postwar affluence their offspring were finally reaping the benefits of their efforts. Yet the baby-boomers felt cut off from their heritage in a culture which they perceived to value only conformity, materialism and corporate uniformity at the expense of diversity. ${ }^{\mathbf{5 1}} \mathrm{A}$ sense of cultural and ethnic identity thus became central to the revivalists. The Old Town School of Folk Music in Chicago, for instance, aimed to encourage young performers to seek out and identify their own roots so that they might understand and celebrate their origins. As Frank Hamilton recalled, "We said, 'Go back to your parents, your grandparents, and their ancestors. Do your musical genealogy. Learn those songs'." 52

However, despite the fact that many of the young revivalists were the descendants of "ethnic" North Americans - Irish, Italian and, particularly, Jewish - one of the remarkable aspects of the revival of the early decade was the fact that the "identity" sought by revivalists was, frequently, not that of their own present or ancestral communities. Rather, the music of other cultures seemed to possess greater mystique; the music of the western and southern States of America - that is, the regions in which "the true American folk" were said to reside - were of particular fascination, but a general preoccupation with "others" who appeared to demonstrate cultural cohesion - including Native North Americans, African Americans and European ethnic groups - was demonstrated by revivalists in both countries. ${ }^{53}$ By this time the revivalists were often far removed from the immigrant backgrounds of their forebears; while their grandparents had struggled hard to conceal their origins in order to assimilate into North American society, their grandchildren perceived their often urban upbringings, in which ethnicity was at times downplayed, as bland and without cultural distinction. Accordingly, as Oscar Brand noted, "meaningful" was

50 As Robert Cantwell demonstrates, revivalists detested the sanitized, derivative music of white "crooners" such as Guy Mitchell, Pat Boone and Frankie Avalon. See Cantwell, When We Were Good, 44-5 I.

${ }^{51}$ Ibid.

52 Quoted in Ronald Cohen, ed., Wasn't That a Time!, I 57.

${ }^{53}$ This process of cultural adoption is in some ways similar to the "dynamic of love and theft" described by Eric Lott in Love and Theft: Blackface Minstrelsy and the American Working Class (New York: Oxford University Press, 1993). 
an adjective frequently employed by young folk revivalists in regard to their choice of music. ${ }^{54}$

The revivalists" perception of the cultural richness and purity of "others" thus led to the focus of the revivalists on a variety of folk groups as a source of "valid cultural experience." young revivalists to imitate, and become "advocates" of, the music of the North American peoples - as demonstrated by Pete Seeger, who was an acknowledged traveller among various cultural and musical worlds and heartily encouraged such imitation and borrowing. ${ }^{56}$ Arguments over the "authenticity" of imitators versus traditional musicians abounded throughout the revival; imitators were never permitted to forget that, no matter how much they resembled the traditional performers, they would always be considered derivative by factions within the movement. At times there was a bitterness, almost a desperation, about this desire for authentic identity. As Oscar Brand remarked,

many of the young singers cannot forgive fate for having started them off in urban environments. They want to be sharecroppers, they want to be dirt farmers, they want to be blind Negro street singers. Since this is denied them, their rage is boundless, and it is turned upon anyone who reminds them of their own roots in modern life. ${ }^{57}$

The concern with authenticity remained central for the revival, and it was a controversy that would never be resolved, since the quest for, and explanation of, personal and community identity was so vital to the movement. The multi-cultural focus of the revival, and its love of the culturally specific, was partially a result of the apparent identity crisis experienced by the postwar generation in North America, a crisis which remains the focus of much research and discussion.

The eclectic character of the folk revival was also closely related to the political stance of many of these same "baby-boomers," perhaps, in particular, those who attended university. Folk music, during the early i96os, continued to go hand in hand with political activism, and thus many of those who loved folk music also participated in civil right struggles and in

${ }^{54}$ Oscar Brand, The Ballad Mongers: Rise of the Modern Folk Song (Westport, CT: Greenwood Press, 1962) 59.

55 I. Sheldon Posen, "On Folk Festivals and Kitchens: Questions of Authenticity in the Folk Revival," in Rosenberg, Transforming Tradition, i 27-36, i 28.

56 See Pete Seeger's defence of imitator Rambling Jack Elliott in Sing Out!, I4, I, Feb.-March I964, 7I-73.

57 Brand, 228. 
the budding student movement. ${ }^{58}$ Folk music, as "experts" reminded their disciples during the revival, had been an instrument of social change for centuries. Building on this tradition, the i96os folk revival intersected with current events; many student activists were revival participants, and often folk musicians were drawn into political activism by their revival activities, and vice versa. ${ }^{59}$ The protest songs of Dylan, Phil Ochs, Tom Paxton and the multifarious contributors to Broadside magazine remain the most direct, obvious link between the revival and ig6os politics, but it is crucial to note that the broader folk movement, with its eclectic perspective, and its particular love of the North American "folk," was inextricably connected to the political philosophies of young people early in the decade. The young white middle-class revivalists, during the early i 960 s at least, still maintained faith in the government to bring about political and social change for the better, and believed that the democratic system would triumph in attaining equality for all social and racial groups. The achievement of "unity in diversity" was a major goal for the youth and civil rights movements of the early i960s, and the revival reflected and promoted this aspiration. The naive, perhaps presumptuous, attitude of white youth in the early i96os that the world might quite easily become a place of diverse peoples in harmony, and their belief in what Daniel J. Gonczy calls the "political and ideological mirage which eloquently bespeaks solidarity,"60 serves to explain, in part, the appeal of folk music to socially conscious young people in the early i96os, and the celebration of cultural pluralism which became so integral to the revival. As student-based movements such as the American Students for a Democratic Society and the Canadian Students' Union for Peace Action (SUPA) devoted themselves to the causes of black civil rights, Native rights and assisting the poor, so too did folk music enthusiasts embrace, above all, and romanticize, the music of groups such as African

${ }^{58}$ Historiography of the white student movement in America is considerable in size and scope. Among the most significant studies of the movement are James Miller, Democracy Is in the Streets: From Port Huron to the Siege of Chicago (New York: Simon and Schuster, 1987); and Terry H. Anderson, The Movement and the Sixties (New York and Oxford: Oxford University Press, 1995). Doug Rossinow's bibliographical essay "The New Left: Democratic Reformers or Left-Wing Revolutionaries?", in David Farber and Beth Bailey, eds., The Columbia Guide to America in the rg6os (New York: Columbia University Press, 200I), 9I-97, discusses these and other related works on the New Left.

59 See, in particular, the work of Guy Carawan, who, with his wife Candie, was active in SNCC and civil rights protests: Freedom is a Constant Struggle (New York: Oak Publications, 1968); and We Shall Overcome! Songs of the Southern Freedom Movement (New York: Oak Publications, I963).

60 Daniel J. Gonczy, “The Folk Music Movement of the ig6os: Its Rise and Fall," Popular Music and Society, io (1985), I 5-31, 23. 
Americans, Native Canadians and the poor white southern and southwestern Americans.

Canadian student protesters who participated in SUPA, in civil rights and in other related humanitarian ventures were, to a considerable extent, driven by a sense of economic and social commonality with their American peers; many believed that Canada, as a Western capitalist country dominated by white people, should share the responsibility of domestic and global exploitation with its southern neighbour. ${ }^{61}$ However, there were some Canadian students for whom activism signified, above all else, a stance highly critical of the United States; these students often advocated that their fellow Canadians should take a nationalistic stand against "imperialistic" America. ${ }^{62}$ Between the two extremes were those who possessed attitudes which resembled, yet also differed from, those of their American counterparts. Their position on civil rights, for example, was often tempered by the feeling that, historically, racism in Canada had been less endemic than in the United States. Ken Whiteley, a Toronto musician who declared that it was to a considerable degree issues of social protest that motivated him to become part of the folk revival, believed that perspectives were different among Canadian youth "perhaps because we were not living to the same extent with the same legacy of racism ... Not to say that Canada doesn't have its own legacy of racism, but a different one. Certainly much less pronounced." against Natives, in particular - having been widespread, but not as potent as in America, was pervasive, and this viewpoint continues, whether accurate or not, to be expressed. Nonetheless, young Canadians who were sympathetic to civil rights did, to a great extent, consider the movement to be of relevance to them and joined with their American counterparts in supporting, and drawing inspiration from, the black freedom fighters of the southern states. In the early i 960 young people in both countries longed for unity and for understanding among cultures, and the pluralism of the folk revival mirrored and helped to promote their optimistic and inclusive political outlook.

${ }^{61}$ See Julyan Reid, "Some Canadian Issues," in Tim and Julyan Reid, eds., Student Power and the Canadian Campus (Toronto: Peter Martin Associates, I 969), 6-1 I.

${ }^{62}$ Cyril Levitt discusses the role of Canadian nationalism in the student movement in Children of Privilege: Student Revolt in the Sixties. A Study of the Student Movements in Canada, the United States, and West Germany (Toronto, Buffalo and London: University of Toronto Press, I 984), I6I.

${ }^{63}$ Whiteley, discussion. A similar opinion was expressed by Richard Flohil during my interview with him. 
Involvement in the revival also carried connotations of exclusivity during the early ig6os, something that was extremely important to many young people at this time. If folk music was not entirely a commercial fad, then it was certainly a cult movement which possessed an "in-crowd" mystique. Involvement in the folk revival was, in the early i 960 s, an indication that one aspired to be intellectual and rebellious, something which seemed incongruous to many older traditional musicians, but which was partially inherited from the beatniks of the I950s, and which would later leave its imprint on the late ig6os rock music culture. Like the beatnik movement, the folk revival attracted many aspiring young intellectuals; folksinger Roy Berkeley recalled that he had found folk music "not only naive but also embarrassing" until he went to Greenwich Village to meet the intellectuals whose ranks he longed to join. "They were intellectuals, thinkers, questioners. And what kind of music did they like? Folk music! I began to look at folk music with a different eye," he recalled. ${ }^{64}$ Thus, for a brief period, folk music was the music of young people who considered themselves discerning and sophisticated.

In an effort to maintain integrity within the revival, commentators often noted that young participants would compete with each other with a mentality which was jokingly termed "folkier than thou." In their efforts to demonstrate that they were devotees only of the "purest" folk music, these revivalists would involve themselves in increasingly obscure forms and styles of music, thus inadvertently further widening the scope of the movement.

The diverse character of the folk revival enabled enthusiasts effectively to "progress" from accessible and popular styles of music to the more rare and specialist genres. As Oscar Brand noted,

Experts aver that many folk fans took up the art in order to be different from the average American. As more people became aficionados, the early adherents were forced to espouse more esoteric forms of folk music - turning from Burl Ives to Bascom Lamar Lunsford, from Lunsford to Pete Steele, and from Pete Steele to whichever backwoods minstrel was as yet undiscovered by the masses. That this group does not represent the majority $\ldots$ is self-evident. ${ }^{65}$

Thus, according to Brand, the more popular folk music became in the mainstream sector, the more obscure and specific the interests of the revivalists. Once again, the "apparatus" of the folk revival served to encourage, and mould the views of, those with special interests or strong opinions on folk music. The workshops held at the major folk festivals

${ }^{64}$ Roy Berkeley, quoted in Ronald Cohen, ed., Wasn't That a Time!, I 88.
${ }^{65}$ Brand, 55. 
encouraged discourse and discussion on very specific genres of folk music, be it bluegrass or traditional Ontario song. Magazines such as the Little Sandy Review catered especially for those who wanted to enter the self-styled "inner circle" of folk music "experts." Sing Out!, in accommodating the views of all parties, ensured that such "experts" could both make their opinions known and argue with those who disagreed with them. Ultimately, the presence of those "experts" who valued the most "rare" or "authentic" folk music, whatever the shortcomings of their attitudes, served also to promote the revival's eclecticism, and ensured that its enquiring spirit and love of detail were kept alive.

\section{CONCLUSION}

The folk revival of the early i 960 in America and Canada was a movement which promoted a vision of the North American continent as a vast patchwork of multi-ethnic, pan-regional societies and cultures. During the early decade there appeared to be little emphasis on nationalism for either the Canadian or the American revival. A sense of Canadian difference was felt in the early movement, but was never outlined in a coherent manner; rather the movement, which had its principal origins in the United States, appealed at this time to Americans who sought a new identity, and to Canadians for whom the North American, pluralistic focus of the movement seemed perfectly relevant.

Gradually, as historians have shown, this changed. ${ }^{\mathbf{6 6}}$ The idealistic outlook of youth in the early ig6os became soured by events in Vietnam and by the proven naivety and impracticality of its political movements. As American youth became disillusioned with their country, celebrations of the forthcoming Canadian centennial were encouraging Canadians to consider themselves proud to be separate from the United States, and to celebrate their "identity," whatever that might be. Simultaneously, events at the 1965 Newport Folk Festival apparently brought the halcyon days of the folk revival to an end. Bob Dylan's "electric" performance at the festival was, however, perhaps less a decisive ending than it was an indication that not merely folk revival music, but also politics and popular music in general, were altering and evolving. The relationship between folk music and national identity in both Canada and America also changed accordingly.

${ }^{66}$ This is the dominant interpretation of the direction of 1960 s politics. See, for example, Michael Kazin and Maurice Isserman, America Divided: The Civil War of the I960s (New York and Oxford: Oxford University Press, 2000); and James Miller, Democracy is in the Streets. 
As Canadians, infused with the nationalism of the centennial era, sought to find ways to portray their folk musicians and singer-songwriters as distinctively "Canadian," many prominent American singer-songwriters with roots in the folk revival, such as Paul Simon and James Taylor, turned inwards, sheltering from the concerns of the outside world which had so preoccupied revivalists. ${ }^{67}$ "Ethnic revivals," which thrived in North America in the I 970 s and I 980 s, owed much to the pluralism of the I960s revivals, but movements such as the revivals of Klezmer and Celtic music often adopted a retrogressive and nostalgic approach to ethnicity and music, perhaps in reaction to the political crises of the I970s. ${ }^{68}$ Nevertheless, despite changing motivations and outlook, "folk music" has remained, by definition, an intensely diverse and catholic musical genre in North America and beyond. However, at no time since the early i 960 s has this diversity been viewed with such self-conscious, unified optimism as was exhibited by the postwar folk revivalists.

${ }^{67}$ For more information on the centennial celebrations and their impact on popular musicians see Wright, "Dream, Comfort, Memory, Despair." For Simon and Taylor see Lorraine Alterman, "Paul Simon: The Rolling Stone Interview," Rolling Stone, 28 May 1970; and "James Taylor: One Man's Family of Rock", Time, I March I 973.

68 The nostalgia and escapism of I 970s America is discussed in Peter N. Carroll, It Seemed Like Nothing Happened: The Tragedy and Promise of America in the 1970s (New York: Holt, Rinehart and Winston, I982). Nostalgia and retrogression in "ethnic" revivals is discussed by Burt Feintuch in "Musical Revival as Musical Transformation," in Rosenberg, Transforming Tradition, I83-93. These trends are discussed in more detail in the book in progress. 